\title{
Effects of Cadmium Chloride on Lymph Node Cells in Rats
}

\author{
Efectos del Cloruro de Cadmio sobre las Células de Linfonodos en Ratas
}

\author{
Deveci, E.** E Erdem, E.**
}

DEVECI, E. \& ERDEM, E. Effects of Cadmium Chloride on lymph node cells in rats. Int. J. Morphol., 31(2):615-617, 2013.

\begin{abstract}
SUMMARY: Cadmium, hazardous heavy metal, is recognized to produce severe toxic effects in humans. In this study, intestinal wall surrounding the mesenteric lymph nodes, based on the cadmium to be mainly lymphocytes and plasma cells, granulocytes eozinofil examined effects on the immune system were investigated by histochemical and electron microscope. Electron microscope examination of the cross section of cadmium, mitochondria cristae in the cytoplasm of lymphocytes was observed deterioration in the structure and degenerative changes in dilated endoplasmic reticulum, were seen together with elongation, that a small number of multi-focal granular lymphocytes, but plasma cells and eosinophilic granulocytes of the structures of multi-focal granular structures of various sizes, and their numbers were much higher.
\end{abstract}

KEY WORDS: Cadmium chloride; Lymph node; Electron microscope examination.

\section{INTRODUCTION}

Human exposure to cadmium due to environmental factors is known to affect several tissues in the body. The major sources of exposure to cadmium are contaminated food and water, tobacco, and industrial fumes and dusts (Goyer $\&$ Cherian, 1995). Toxic effects of $\mathrm{Cd}$ have also been demonstrated on the bone formation and immune system (Nordberg, 1996) and (Waalkes et al., 1999). Cadmium causes damage both to humoral immune response and cell mediated immunity (Descotes, 1992; Dan et al., 2000). Cifone et al. (1989) demonstrated that the exposure to 200 and 400 ppm Cd of adult rats caused both inhibitory and stimulatory effects on natural killer cells activity and cytotoxic activity. Moreover, Hemdan et al. (2006) reported that $\mathrm{Cd}$ treatment exerted differential effects on cytokine production in human immunocompetent cells. Immunotoxic properties of most heavy metals is not well lit, and the underlying mechanisms are not fully understood. Therefore, the aim of this study, an important immune-modulating properties of cadmium in environmental and occupational toxins on the ultrastructural level to examine and lymphocytic system created to show the damage.
MATERIAL AND METHOD

Nine-week-old Wistar rats 180-200 g body weight were used in these trial and were divided in two groups of 24 animals each (control group and experimental group). The control group received $1 \mathrm{ml}$ of $0.9 \% \mathrm{NaCl}$ intraperitoneally every day for one week. Rats in the experimental group received $2 \mathrm{mg} / \mathrm{kg} / \mathrm{gun}$ powdered cadmium chloride dissolved in water intraperitoneally every day for one week. All of the animals were individually housed in stainless steel cages at room temperature. Animals had free access to Standard laboratory rat pellet and water ad libitum. Animals were sacrificed by decapitation under ether anesthesia, mesentery lymph nodes surrounding the intestinal wall was located. The pieces of tissue were immediately placed in $2.5 \%$ glutaraldehyde, buffered for $4 \mathrm{~h}$, then fixed in $\mathrm{OsO} 4$ for $2 \mathrm{~h}$, dehydrared in graded ethanols, and embeded in araldite. Semithin sections of $1 \mu \mathrm{m}$ thick were cut and stained with methylene blue-azure II for light microscopic examination. Thin sections of $70 \mathrm{~nm}$ thick were stained with lead citrate-uranyl acetate and examined and photographed under Zeiss Electron microscope 9S.

\footnotetext{
*Department of Histology and Embryology, Dicle University School of Medicine, Diyarbakır, Turkey.

**Artuklu University School of Health, Mardin, Turkey.
} 


\section{RESULTS AND DISCUSSION}

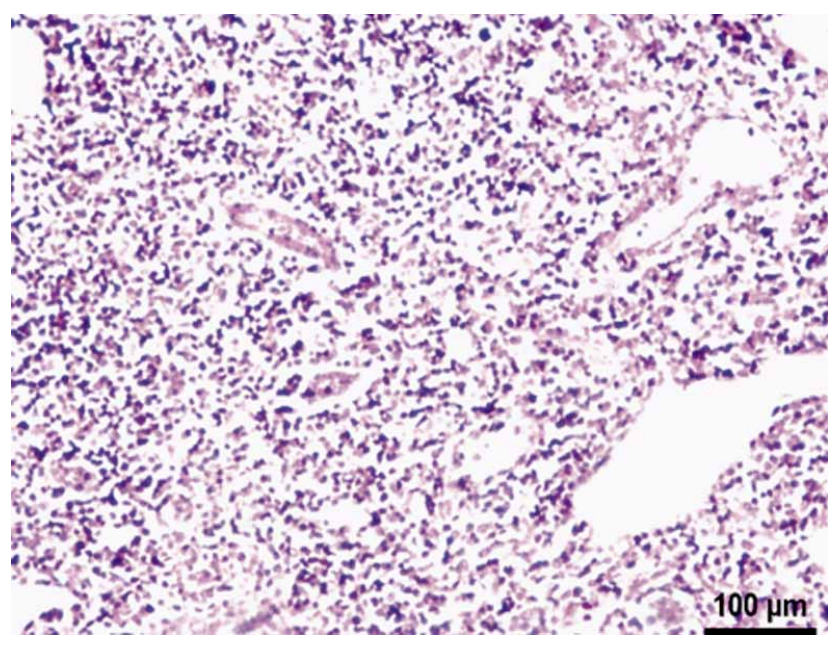

Fig. 1. Normal appreance of lymph node (Control group).

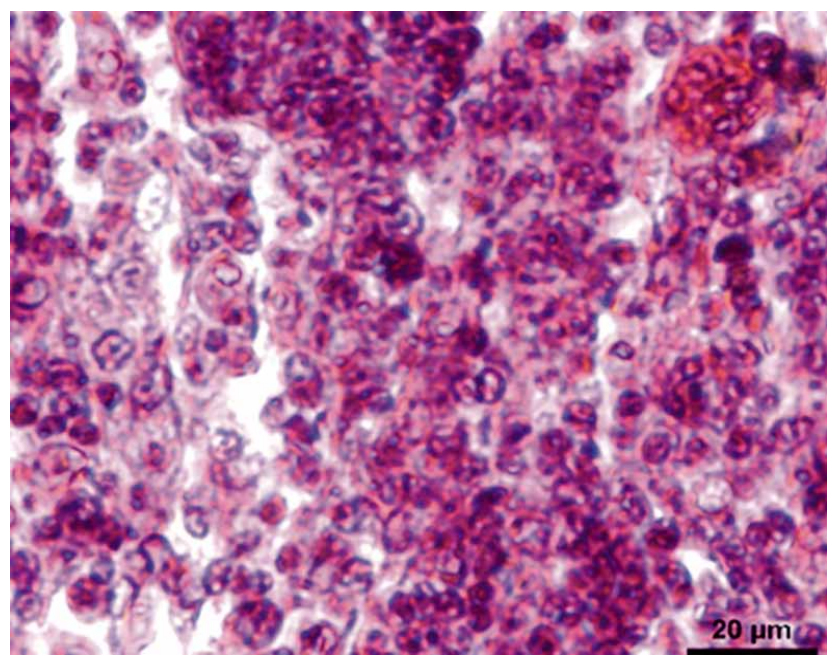

Fig. 2. Some types of medium and small lymphocytes and lymphocyte cells in the nucleus of cells piknosis hypertrophy and apoptosis.
This study examined cadmium-treated group as compared with the control group sections. Light microscopic examination; Lymphocyte cells, no change was observed in the control group (Fig. 1). Some types of medium and small lymphocytes and lymphocyte cells in the nucleus of cells piknosis hypertrophy and apoptosis were seen. Solitary lymph follicles outside the blood vessels, hemorrhage, and freely distributed in the erythrocytes were observed (Fig. 2). Cadmium-treated group in another section, the plasma cell degeneration, cellular infiltration was observed in the rise and expansion of the sinuses (Fig. 3). Electron microscope examination of the control group sections, the center of a large number of small nucleolar heterochromatic nuclei of lymphocytes were seen. Iliac crests and welldeveloped mitochondria in the cytoplasm, nuclear periphery tubular manner towards a small number of cisternae of the endoplasmic reticulum Golgi bodies were seen.

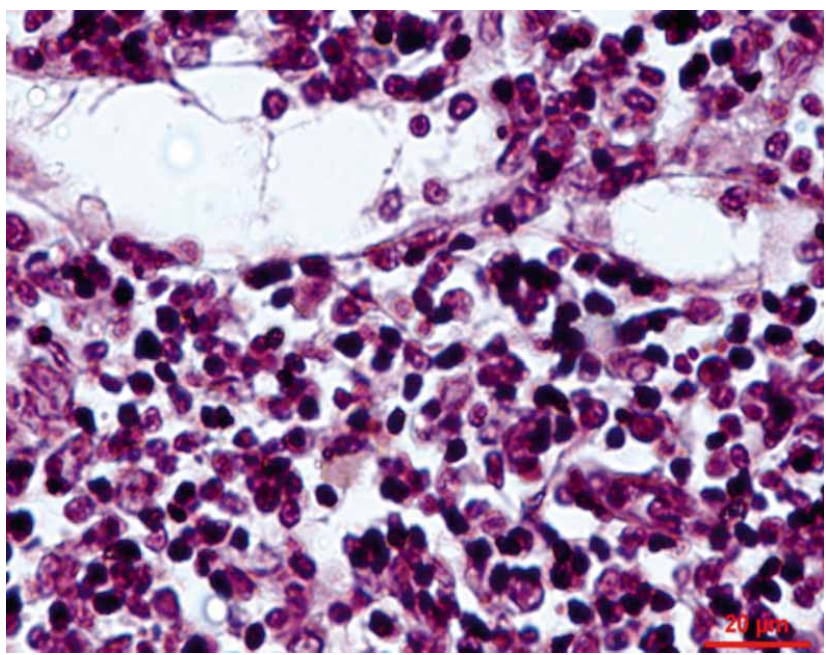

Fig. 3. The plasma cell degeneration, cellular infiltration was observed in the rise and expansion of the sinuses.

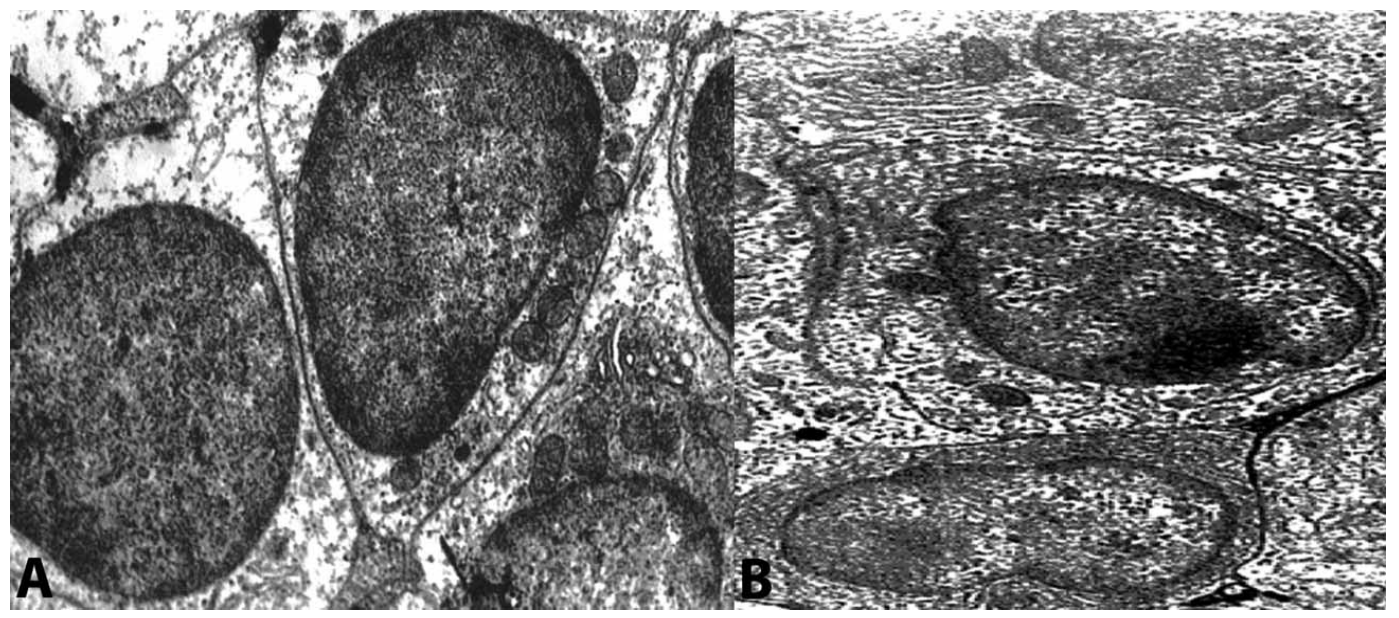

616
Fig. 4. A. Appereance of lymphocyte cells in control group (Uranyl acetate- lead citrateX8800). B. Dilation of endoplazmic reticulum and degeneration in mitochondria of lymphocyte cells (Uranyl acetate- lead citrate- X8800). 
Electron microscope examination of the cross section of cadmium, mitochondria cristae in the cytoplasm of lymphocytes was observed deterioration in the structure and degenerative changes in dilated endoplasmic reticulum, were seen together with elongation (Fig. 4B) That a small number of multi-focal granular lymphocytes, but plasma cells and eosinophilic granulocytes of the structures of multi-focal granular structures of various sizes, and their numbers were much higher. Depending on the effect of cadmium chloride in particular, lymphocytes, degeneration of mitochondrial cristae thought to trigger apoptosis with cell depolarization.

Koller et al. (2001) explored the effect of heavy metals study, lymphocytes and histiocytes in the renal interstitium is a multi-focal granuloma, spleen, thymus, lymph node, have found the same lesions. In our study, although the small number of lymphocytes in the middle type of multi-focal granular structures were observed in the cytoplasm. multi-focal granular lymphocytes minimal structures, seen a number of plasma cells and secretion eosonofil growth, reveals the effect of immune and allergic reactions. Cadmium chloride effects on lymphocytes in the thymus was investigated, the study indicated that changes in lymphocytes of necrosis occurred and mitochondrial structures. Necrotic cells were not observed changes in the crystalline structure of lymphocyte study, a slight deterioration was observed in mitochondria. Lymphocyte cells of the cellular damage caused by heavy metals cadmium think that will affect the immune system.

DEVECI, E. \& ERDEM, E. Efectos del cloruro de cadmio sobre las células de nódulos linfáticos en ratas. Int. J. Morphol., 31(2):615617, 2013.

RESUMEN: El cadmio, es un peligroso metal pesado, reconocido como causante de graves efectos tóxicos en los humanos. En este estudio, se examinaron los efectos del cadmio sobre el sistema inmune en la pared intestinal que rodea a los nódulos linfáticos mesentéricos, principalmente linfocitos, células plasmáticas y granulocitos eosinófilos, mediante técnicas histoquímicas y microscopía electrónica. En el examen mediante microscopía electrónica de la sección transversal de la pared intestinal sometida al cadmio, se observó un deterioro estructural de las crestas mitocondriales en el citoplasma de los linfocitos y cambios degenerativos en el retículo endoplásmico, además fueron vistos con un pequeño número de linfocitos granulares, células plasmáticas y granulocitos eosinófilos con estructuras granulares multifocales de diversos tamaños y más altos.

PALABRAS CLAVE: Cloruro de cadmio; Nódulos linfáticos; Microscopio electrónico.

\section{REFERENCES}

Cifone, M. G.; Alesse, E.; Di Eugenio, R.; Napolitano, T.; Morrone, S.; Paolini, R.; eta l. In vivo cadmium treatment alters natural killer activity and large granular lymphocyte number in the rat. Immunopharmacology, 18(3):149-56, 1989.

Dan, G.; Lall, S. B. \& Rao, D. N. Humoral and cell mediated immune response to cadmium in mice. Drug Chem. Toxicol., 23(2):349-60, 2000.

Descotes, J. Immunotoxicology of cadmium. IARC Sci. Publ., (118):385-90, 1992.

Goyer, R. A. \& Cherian, M. G. Toxicology of Metals: Biochemical Aspects, Handbook of Experimental Pharmacology. New York, Springer-Verlag, 1995. pp.189-213.

Hemdan, N. Y.; Emmrich, F.; Sack, U.; Wichmann, G.; Lehmann, $\mathrm{J}$.; Adham, K.; et al. The in vitro immune modulation by cadmium depends on the way of cell activation. Toxicology, 222(1-2):37-45, 2006.

Koller, L. D.; Stang, B. V.; de la Paz, M. P. \& Ruiz Mendez, M. V. Pathology of "toxic oils" and selected metals in the MRL/lpr mouse. Toxicol. Pathol., 29(6):630-8, 2001.
Nordberg, G. F. Current issues in low-dose cadmium toxicology: nephrotoxicity and carcinogenicity. Environ. Sci., 4:133-47, 1996.

Waalkes, M. P.; Anver, M. R. \& Diwan, B. A. Chronic toxic and carcinogenic effects of oral cadmium in the Noble (NBL/Cr) rat: induction of neoplastic and proliferative lesions of the adrenal, kidney, prostate, and testes. J. Toxicol. Environ. Health A, 58(4):199-214, 1999.

Correspondence to:

Engin Deveci

Associate Professor (PhD)

Department of Histology and Embryology

Dicle University, School of Medicine

21280 Diyarbakır

TURKEY

Email: engindeveci64@gmail.com

Received: $10-05-2012$

Accepted: 22-11-2012 